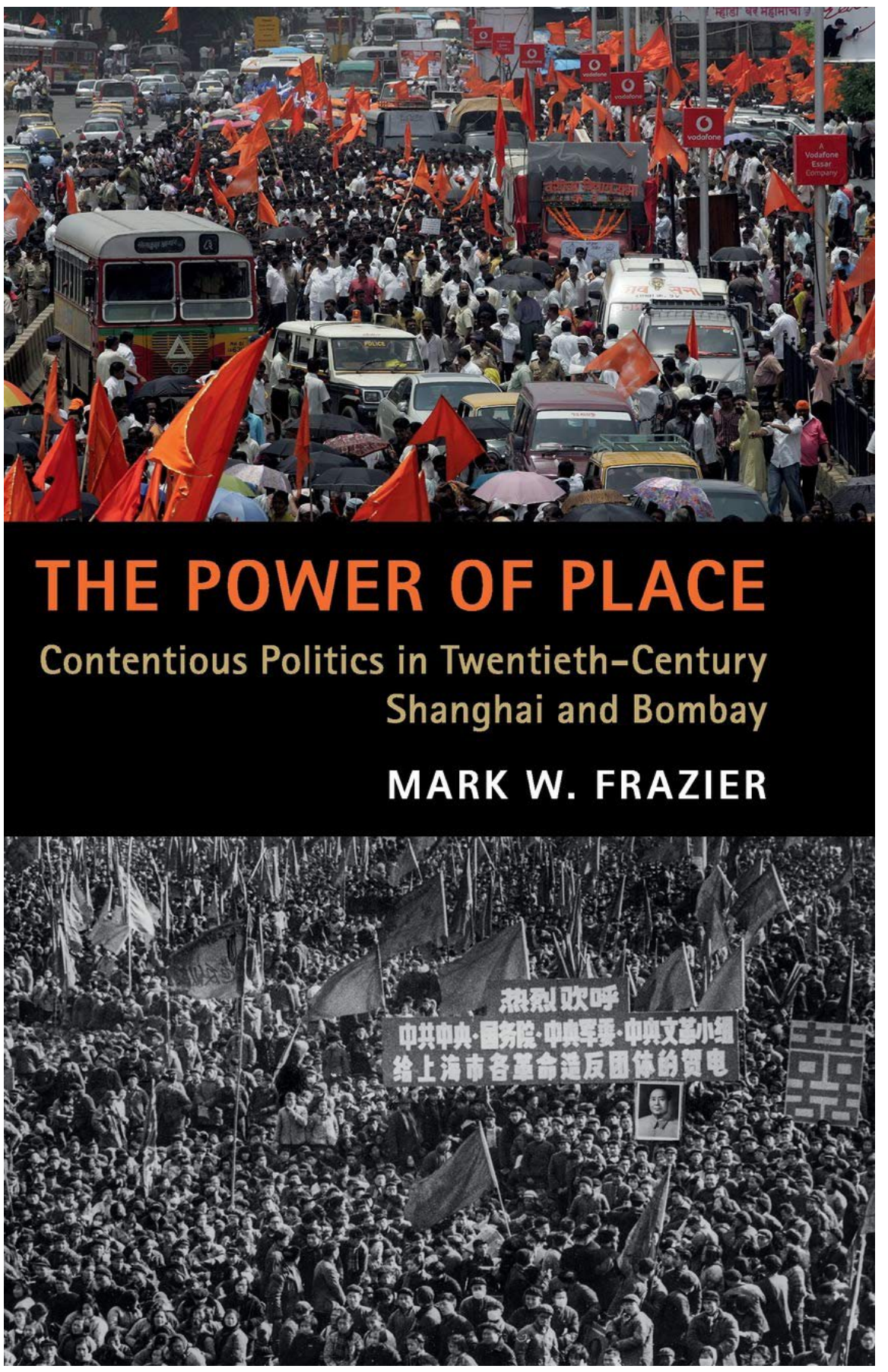

The Power of Place: Contentious Politics in Twentieth-Century Shanghai and Bombay (Cambridge University Press 2019) 


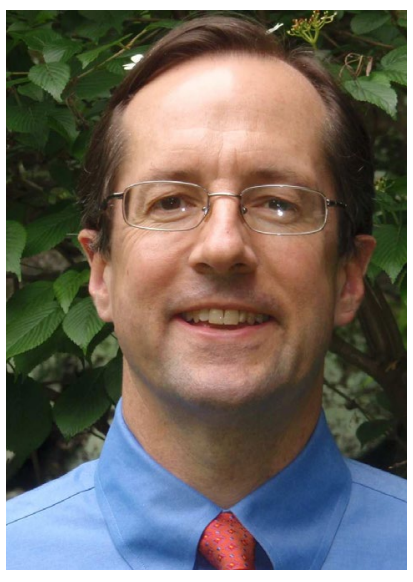

Mark Frazier

\section{The Power of Place A Conversation with Mark Frazier}

Ivan FRANCESCHINI

Shanghai and Mumbai are leading centres of manufacturing and finance. In The Power of Place: Contentious Politics in Twentieth-Century Shanghai and Bombay (Cambridge University Press 2019), Mark Frazier adopts a comparative historical lens to chronicle the political biographies of these metropolises, reconstructing an impressive series of riots, strikes, and protests that shook the two cities in the twentieth century. In so doing, he unearths hidden connections that provide new insight into contemporary debates over informal housing, eviction of innercity residents, scarcities of manufacturing jobs, and questions of unequal citizenship.

Ivan Franceschini: What brought you to compare two cities as different as Shanghai and Mumbai?

Mark Frazier: They are not as different as one might think. Yes, they are located in nation-states (some would say civilisationalstates) with stark contrasts in culture, religion, and politics, but as cities they have a great deal in common, especially when one looks at their trajectories from the mid-nineteenth to the midtwentieth century. Both cities became global trading hubs under nineteenth-century British colonial capitalism. Shanghai's emergence as a global textile manufacturing centre owed its origins in part to the import of cotton yarn from Bombay mills in the nineteenth century. In the first decades of the twentieth century, both cities saw the emergence of potent nationalist movements, which also sought to link up with labour agitation among the textile workers. The textile industry was the leading employer in both cities for much of the twentieth century, and the site of frequent strikes.

The even more surprising convergences came as I studied the 1950s, when similar political trends emerged under two quite different regimes: the demobilisation of labour unions, the repression of popular protests, and a growing resentment over the allocation of urban goods and services (especially housing and jobs) to insiders-Party officials and loyalists in the case of Shanghai, and 'alien' non-native Indian elites in the case of Bombay. These resentments broke out, in very different ideological currents, in the very same year, 1966, which saw the 
rise of the Shiv Sena as a nativist movement in Bombay and the rise of numerous organisations with socioeconomic grievances in the context of the Cultural Revolution in Shanghai.

In the late twentieth century, both cities (re)opened to global and regional capital flows. With the liberalisation of land ownership policies, land prices soared and gave rise to vast wealth among insiders who could leverage the policies to their advantage (district government officials in the case of Shanghai, private capitalists in the case of Mumbai). Land-led development also wiped out the manufacturing sector in both cities in short order by the early twenty-first century. Mumbai's pace of urban transformation has indeed been slower than Shanghai's (no city can rival Shanghai in that respect), but the very fact that Mumbai elites use Shanghai as a common reference point for the kind of urban transformation they would like to see is another recent example of the many historical connections and comparisons one can make between the two cities.

\section{IF: You describe long series of citywide protests in response to political and economic inequality that took place in both Mumbai and Shanghai throughout the twentieth century. You then show how by the end of the past century this kind of popular mobilisation had given way to fragmented protests, largely against residential relocation and redevelopment projects. How do you explain this shift?}

MF: I came at this project with an assumption that one hears frequently-that rising levels of inequality generate political conflict. If that is true, one would expect to see ever-rising levels of tension and conflict in the two cities with or near the highest levels of income inequality in their respective countries. Shanghai and Mumbai have seen significant protests during the late twentieth and early twenty-first centuries, as income inequalities rose, but these pale in comparison to the massive rallies and marches that one finds before then. So there is more to sustained protest movements than simply rising income inequality.

In the last section of the book, I discuss the ways in which both cities have undergone rapid de-industrialisation, including the disappearance of the politically powerful textile industry and its workers. The main cause of de-industrialisation was the rapid rise in land prices, which made manufacturing zones much more profitable for commercial and residential uses. At the same time, new housing policies have changed the landscapes of both cities as well as what people protest about. In both cities, textile workers and their families have been compensated for the loss of the industry by housing policies that essentially grant ownership (after a required period of residence) to the workers. 
These 'relocation housing' projects are today prominent in the Shanghai suburbs and in Mumbai's old mill districts. The former proletariat (literally, 'propertyless') have become small property owners of units that have seen tenfold increases in the value of the property over the past decade. There is no solid proof that housing ownership alters political outlooks, but protests have become more localised in scope-grievances arise from poor provision of public services in the relocated housing areas, and from 'not in my backyard' reactions to industrial or other facilities seen as dangerous or harmful to property values.

IF: In spite of this break, is it possible to identify elements of continuities across time in terms of political geography and contentious politics in the two cities?

MF: The common thread is that urban political geography can help us understand broad patterns of popular protest. The Power of Place makes two main claims: first, that changes over time in the layout of the city-its industrial zones, housing stock (including tenement housing), civic spaces, and migrant neighbourhoods are associated with new forms of identity and agency in contentious politics. Second, movement organisers and leaders tend to successfully mobilise the urban populace when they situate their ideologies and broader claims in terms of local grievances. For example, the Communist Party of India (CPI) in Bombay in the 1920s was far more successful than the Chinese Communist Party (CCP) operating in Shanghai at the same time. This was because the communists in Bombay eschewed class and ideological questions in favour of community organising in the textile mill districts. When the time came to confront employers, they had much more support from workers as a result. The CCP in Shanghai eventually learned this lesson, short-lived though it was, in mobilising a broad coalition during the Three Armed Workers' Uprisings in 1926-7-during which they called for a city self-ruled by citizens, free of warlord and imperialist domination. In a similar pattern, the rise of the Shiv Sena in the 1960s-and their violent expulsion of the CPI from the mill districts, stemmed from their impressive community-organising efforts, based on a kind of constructed victimhood of the local Marathi-speaking population. The Shiv Sena remains a political force in Mumbai today, frequently garnering support to stand as the ruling party in both municipal and state governments. Of course, in contemporary Shanghai it is impossible to mobilise an organised opposition based on local grievances, but the CCP from its early days in governing Shanghai and all other cities quickly established a grassroots governance of neighbourhood and residence committees that mediated and addressed issues stemming from housing, social 
services, and other community concerns. One of the reasons that the CCP today so obsessively controls the work of NGOs is the fear that NGOs might attain a certain degree of autonomy and political support at the expense of the $\mathrm{CCP}-$ for example, an NGO that organises services and support for migrant workers within urban villages.

\section{IF: Do you think that your analysis can broadened to other 'global cities' of today?}

MF: I am less interested in the concept of 'global cities'-a term that suggests a group of cities with dense linkages to each other in the form of professions, corporations, consumption, business districts, etc. Shanghai and Mumbai would qualify for that label by most measures, but what I am suggesting goes beyond global cities. My study of political geography and popular protest in twentieth-century Shanghai and Mumbai was motivated in part by the pattern seen in several large-scale protests in the mid 2010s-the Occupy movements around the world and the Arab Spring protests. These urban uprisings arose from different sources and voiced different demands, but they seemed to be quite adept at deploying their ranks in strategically or symbolically important civic spaces. I think the analysis in Power of Place tries to explore the connections between place and protest, not by confirming specific hypotheses for universal application but in developing propositions that could offer insights in other cases of urban contentious politics.

A clear example of the connections between place and protest can be found in Hong Kong. The gradual integration with the mainland in terms of infrastructure, tourism, and education policies (among much else) over the past decade emboldened a latent Hong Kong identity, and prompted sustained protests against the local government for undermining local autonomy under the one country, two systems formula. In the Hong Kong of 2019 (as also seen in my chapter on anti-imperialist protests in Shanghai and Bombay in 1919), protestors held marches and short-term sit-ins in strategic sites of imperial power (a Beijing-dominated Legislative Council, for example), boycotted businesses deemed to have pro-Beijing stances, and demanded the withdrawal of a proposed piece of legislation seen as coming from Beijing. In Bombay in 1919, citizens mobilised against the renewal of British anti-sedition laws, and in Shanghai of course it was an international treaty reflecting the dominance of great powers (including Japan) at China's expense. So in this sense, my analysis could be used as a kind of heuristic device to study patterns of urban popular protest, by looking at changes in political geographies, especially for civic space, residential and 
work patterns, migrant enclaves, etc., and how these changes influence conceptions of citizenship and claims against state power at local, national, and even international scales. 
This text is taken from Made in China Journal: Volume 5, Issue 1, 2020, edited by Ivan Franceschini, Nicholas Loubere and Christian Sorace, published 2020 by ANU Press, The Australian National University, Canberra, Australia.

doi.org/10.22459/MIC.05.01.2020.27 